University of Nebraska - Lincoln

DigitalCommons@University of Nebraska - Lincoln

\title{
A Rare Epidemic of Sugar Beet Seedling Rust in Nebraska
}

Robert M. Harveson

University of Nebraska-Lincoln, rharveson2@unl.edu

Follow this and additional works at: https://digitalcommons.unl.edu/panhandleresext

Part of the Agriculture Commons

Harveson, Robert M., "A Rare Epidemic of Sugar Beet Seedling Rust in Nebraska" (2011). Panhandle Research and Extension Center. 61.

https://digitalcommons.unl.edu/panhandleresext/61

This Article is brought to you for free and open access by the Agricultural Research Division of IANR at DigitalCommons@University of Nebraska - Lincoln. It has been accepted for inclusion in Panhandle Research and Extension Center by an authorized administrator of DigitalCommons@University of Nebraska - Lincoln. 
36th Biennial Meeting of the American Society of Sugar Beet Technologists 2011, Albuquerque, New Mexico, USA, 2-5 March 2011 Copyright@ (2011) by the American Society of Sugar Beet Technologists

\title{
A RARE EPIDEMIC OF SUGAR BEET SEEDLING RUST IN NEBRASKA
}

\author{
Robert M. Harveson \\ Panhandle Research and Extension Center, University of Nebraska \\ 4502 Ave I, Scottsbluff, NE 69361
}

\begin{abstract}
Sugar beet seedling rust, caused by Puccinia subnitens, is a disease that has rarely been observed in sugar beet production. The pycnial and aecial stages occur on sugar beets, while the uredial and telial stages infect the primary host, inland saltgrass (Distichlis spicata). In mid-May 2009, lesions indicative of sugar beet seedling rust were found on young sugar beet plants in a field near Bayard, Nebraska. Because of the continued cool weather with above average precipitation throughout May, a survey of sugar beet production fields in western Nebraska was conducted between late-May and mid-June to further document the incidence and distribution of seedling rust caused by $P$. subnitens. Over this time period, 37 of 57 (65\%) scouted locations, representing 8 counties in Nebraska contained sugar beet or common lambsquarter plants with pycnia and/or aecia of $P$. subnitens. The majority (89\%) of those pathogen-infested fields were located within two counties in the North Platte Valley (Scotts Bluff and Morrill). A similar survey was conducted during May and June 2010, with only 26\% of monitored locations yielding infected plants (8 of 31). The results from this survey during 2009-2010 represent the first time the disease has been found occurring naturally from field infections in Nebraska and anywhere else in the world for almost 100 years.
\end{abstract}

\section{Introduction:}

Sugar beet seedling rust, caused by the macrocyclic, heteroecious, pathogen Puccinia subnitens (syn. $P$. aristidae), is a rare disease in sugar beet production. Only the pycnial and aecial stages occur on sugar beet, while the other stages (uredial and telial) infect the primary host, inland saltgrass (Distichlis spicata) (1). Seedling rust was reported to cause moderate damage to sugar beets in the Rocky Ford area of Colorado in 1912-1913 (4), and since the 1940's, sporadic epidemics attributed to the same pathogen have induced severe losses in Colorado spinach production (3). The telial stage of the pathogen was reportedly found abundantly on stands of inland saltgrass within close proximity of both spinach and sugar beet fields infected with the aecial stage $(3,4)$. Inland saltgrass is a warm season grass native to arid areas of the western U.S. The plant is commonly found in brackish, marshy areas or highly saline soils (2), and is very drought tolerant and thrives in the strongly alkaline soils of western Nebraska.

In mid-May 2009, signs indicative of sugar beet seedling rust were first found on young sugar beet plants in a field near Bayard, Nebraska after a period of unusually cool and wet weather had prevailed throughout the western Nebraska Panhandle in late spring. Temperatures during these two months were $13^{\circ} \mathrm{C}$ cooler with $12 \mathrm{~cm}$ higher rainfall than 
the 30 year average for this area. Disease incidence in this field approached 25\% although lesions were restricted primarily to the cotyledons.

The pathogen was identified by the presence of circular, light-yellow pycnial lesions, 2-5 mm in diameter, containing flask-shaped pycnia and yellowish-orange aecia aggregated in rings. Aeciospores measured approximately 17-22 $\mu \mathrm{m}$ x 15-20 $\mu \mathrm{m}$ and were globoid in shape with finely verrucose walls (1). This field was monitored 5-6 times over the entire season and no uredial pustules were ever observed on sugar beet plants, effectively ruling out beet rust as the causative factor in this field. Beet rust is a distinct disease caused by the macrocyclic, autoecious pathogen Uromyces betae. The original affected sugar beet field was surrounded by stands of inland saltgrass infected with the telial stage of a rust pathogen, presumed to be $P$. subnitens, but not confirmed.

\section{Survey of Sugar Beet Fields 2009-2010:}

After the initial identification of the pathogen in Morrill County near Bayard, Nebraska in mid-May, 2009, a survey of sugar beet production fields in western Nebraska was conducted between late-May and mid-June to further document the incidence and number of fields infested with seedling rust caused by $P$. subnitens.

Over this period, 57 locations from 8 western Nebraska counties (Scotts Bluff, Morrill, Box Butte, Banner, Kimball, Sioux, Cheyenne, and Sheridan) were scouted and 37 were found to contain plants with pycnia and/or aecia of P. subnitens. The pathogen was found infecting sugar beets from 33 sugar beet fields. Lambsquarters (Chenopodium album) plants, another reported host of $P$. subnitens $(3,4)$, infected with pycnial and aecial stages of the pathogen were additionally identified from $30 \%$ (10/33) of the pathogen-infested beet fields. Four additional sites yielded infected lambsquarters, including two ditchbanks, an uncultivated field, and a home garden. By the end of the survey in mid-June, the majority of the pathogen-infested fields (89\%) were located within the North Platte Valley (Scotts Bluff and Morrill Counties). The pathogen was identified from only four fields outside the Valley (two each in Kimball and Box Butte Counties).

Due to similar environmental conditions as experienced in 2009, a similar survey was conducted during May and June 2010, from more than thirty locations throughout western Nebraska. In fact, the pathogen was found on a lambsquarters plant growing in the flower bed of a local restaurant in the city of Scottsbluff in early June. However, the incidence within and among fields was lower in 2010 with only 26\% of monitored locations yielding infected plants (8 of 31). As in 2009, the majority of the infections were detected from fields in Scotts Bluff and Morrill counties.

\section{Further Results:}

It is not known why the distribution of seedling rust was so heavily clustered in the two counties in the North Platte Valley. The few published reports of this disease concluded that the pathogen occurred primarily on cotyledons and occasionally the first true leaves $(1,2,4)$, hence the name seedling rust. However, this study further documented the occurrence of multiple infections from many of the surveyed sites. Twenty percent of fields (18 of 88) from both years contained plants with pycnial lesions 
on newly emerged leaves in June. These observations indicate multiple cycles of basidiospore release after May from the alternate host followed by new infections on beets long past the cotyledon or first true leaf stage (up to 5-6 the true leaf stage).

\section{Conclusions:}

Seedling rust on sugar beets is not economically damaging (1). However, diagnosing the disease during these seasons provided the foundation for recognizing future outbreaks. Additionally, by correctly diagnosing the disease rapidly, fungicide applications, which would have been made due to the unknown nature of the problem, were avoided. The occurrence of seedling rust is apparently very rare. The unusually cool and wet weather during the 2009-2010 growing seasons, coupled with the common presence of pathogen-infected saltgrass stands in this region of Nebraska, undoubtedly contributed to the high incidence of fields infested with the pathogen.

\section{Literature Cited:}

1. Hanson, L. E. 2009. Beet rust and seedling rust. Pages 12-13 in: Compendium of Beet Diseases and Pests, $2^{\text {nd }}$ edition. R. M. Harveson, L. E. Hanson, and G. L. Hein, eds. APS Press, American Phytopathological Society, St. Paul, 140 pp.

2. Newman, S. D., Gates, M., and Materne, M. 2006. Saltgrass. USDA, NRCS Plant Guide. 4 pp.

3. Oshima, N., Henderson, W. J., and Dickens, L. E. 1960. The occurrence of spinach rust in Colorado. Plant Dis. Reptr. 44: 828-829.

4. Pool, V. W., and McKay, M. B. 1914. Puccinia subnitens on the sugar beet. Phytopathology 4: 204-206. 